DOI: 10.46340/eppd.2021.8.3.22

\author{
Viktor Kaliuzhnyi \\ ORCID ID: https://orcid.org/0000-0003-1976-8485 \\ Zaporizhzhia National University, \\ National Police, Department of Strategic Investigations in Chernihiv region, \\ Ukraine
}

\title{
CURRENT PROBLEMS OF CIVIL LEGAL PROTECTION OF HOUSING RIGHTS ACCORDING TO THE LEGISLATION OF UKRAINE
}

\author{
Віктор Калюжний \\ Запорізький національний університет, \\ Національна поліція, УСР в Чернігівській області, Україна
}

\section{АКТУАЛЬНІ ПРОБЛЕМИ ЦИВІЛЬНО-ПРАВОВОГО ЗАХИСТУ ЖИТЛОВИХ ПРАВ ЗА ЗАКОНОДАВСТВОМ УКРАЇНИ}

The article examines current issues of civil law protection of housing rights under the laws of Ukraine. It is determined that in the special legal literature the problem of civil protection of housing rights was the subject of a limited number of scholars. In addition, these problems were divided in fragments on the protection of property rights or contractual obligations, a limited number of persons (family members, children, children deprived of parental care), in relation to a limited range of relationships.

It is determined that among the urgent problems of civil law protection of housing rights there are the problems that have manifested themselves in relatively new relationships due to the economic crisis, which resulted in the inability of individual citizens to meet their mortgage obligations of commercial banks, and now lifting the moratorium on satisfaction of claims under such obligations, in particular, on the application of foreclosure on housing for the purchase of which such loans were provided; relations in the field of housing and communal services; relations in the field of realization of housing rights in the activities of condominiums; relations in the field of privatization of the state housing stock, realization of the rights of residents of dormitories, granting and use of housing stock of social purpose; providing compensation to persons whose homes were destroyed as a result of Russia's armed aggression in the Ukrainian-controlled territories of Donetsk and Luhansk regions, etc.

It is argued that the problem of protection of legitimate housing interests, which are a prerequisite for the emergence and implementation of housing rights of citizens, is unreasonably ignored by scientists and legislators.

Keywords: housing rights, right to housing, protection of housing rights, protection of housing interests, personal intangible rights.

Постановка проблеми. Житло $є$ необхідною складовою життя людини. Життя людини просто немислиме без житла, яке забезпечує сферу приватного буття людини, сферу приватності. Закономірно, що право на житло, на визнання цього права та повагу до житла визнане як на міжнародному, так і на національному рівнях. Але саме лише визнання права та його нормативне закріплення не $є$ достатньою його гарантією. Саме лише визнання права, не підкріплене можливістю його реального здійснення, не забезпечене можливістю правового захисту, не може бути визначеним як охоронюване законом право. Необхідний механізм забезпечення права людини, який включає в себе механізм його охорони, здійснення та захисту. Тож захист є необхідним складовим елементом такого механізму. Наразі в цивільному праві України вироблено форми 
та способи захисту житлових прав, які включають речові та зобов'язальні способи їх захисту. Їх застосування зумовлене способом та характером порушення житлового права, - узв'язку 3 невиконанням чи неналежним виконанням договору чи порушенням речового права носія житлових прав. Водночас, в науковій юридичній літературі останнім часом все частіше звертається увага на правову природу житлових прав, які поєднують як майнову так і особисту немайнову складову, особливо коли йдеться про порушення особистого немайнового права чи законного інтересу. Безперечно, що якщо майновій складовій приділено більшу увагу, то щодо немайнової, лише визначається зумовленість обрання та застосування форм та способів захисту житлового права особи характером, правовою природою порушеного особистого немайнового права та характером його порушення. Та все ж, це загальні підходи, які знаходять свій прояв в конкретних ситуаціях. Особливість та унікальність житлових прав потребує застосування виваженого спеціалізованого та диференційованого підходу до їх захисту. В Україні останнім часом виявилася низка нових проблем та викликів, які потребують свого нагального вирішення. Серед них вирішення наслідків економічної кризи, яка унеможливила виконання українцями зобов'язань за іпотечними договорами з придбання житла, захист житлових прав та законних інтересів у відносинах, пов'язаних з функціонуванням ОСББ (об'єднань співвласників багатоквартирних будинків), надання житлово-комунальних послуг та ін. Попри закріплення у ст. 25 Загальної Декларації прав людини 1948 р. положень, що кожна людина має право на такий життєвий рівень, включаючи їжу, одяг, житло, медичний догляд та необхідне соціальне обслуговування, який $\epsilon$ необхідним для підтримання здоров'я і добробуту іï самої та їі сім'ï, і право на забезпечення в разі безробіття, хвороби, інвалідності, вдівства, старості чи іншого випадку втрати засобів до існування через незалежні від неї обставини, саме економічні негаразди поставили під сумнів можливість безперешкодного здійснення природного права на житло.

Стаття 3 Конституція України прямо закріпила, що права і свободи людини та їх гарантії визначають зміст і спрямованість діяльності держави. Держава відповідає перед людиною за свою діяльність. Утвердження і забезпечення прав і свобод людини є головним обов'язком держави. Державою прикладено чимало зусиль для виконання цих положень Конституції України. Серед них, фінансування субсидій громадянам, які не мають достатніх коштів для сплати вартості комунальних послуг, введення мораторію на звернення стягнень на житло за іпотечними кредитами, правове регулювання функціонування ОСББ (об’єднань співвласників багатоквартирних будинків). Тим не менше, прогалини, недоліки та протиріччя чинного законодавства породжують низку проблем, що мають наслідком порушення житлових прав чи охоронюваних законом житлових інтересів. Ці проблеми потребуються свого нагального вирішення, зокрема, в частині забезпечення цивільноправового захисту житлових прав та законних інтересів в цих відносинах.

Наразі існує чимало питань, пов'язаних із захистом житлових прав та інтересів осіб, які було порушено при здійсненні у відносинах у сфері надання житлово-комунальних послуг; усфері реалізації житлових прав в діяльності ОСББ; відносинах у сфері приватизації державного житлового фонду, здійснення прав мешканців гуртожитків, надання та користування житловим фондом соціального призначення; надання компенсацій особам, житло яких зруйноване внаслідок збройної агресії Росії на підконтрольних Україні територіях Донецької та Луганської областей та ін.

Аналіз останніх досліджень з тематики. Окремі питання, які стосуються дослідження відносин у сфері здійснення права на житло, були предметом невеликого кола науковців. Серед них: дисертаційне дослідження М.К. Галянтича «Приватноправові засади реалізації житлових прав громадян в Україні» (2008), А.А. Фігель «Цивільно-правовий захист житлових прав фізичних осіб» (2012), О.В. Мовчан «Цивільно-правовий захист житлових прав дітей» (2015), О.М. Коршакової «Захист прав споживачів житлово-комунальних послуг: цивільно-правовий аспект» (2015), О.В. Коваль «Захист права на житло дітей-сиріт та дітей, позбавлених батьківського піклування» (2015), наукова стаття Хіміч С.П. «Захист житлових прав у контексті застосування Свропейської конвенції про захист прав людини» (2015), доповідь на науково-практичній конференції М.К. Галянтича «Проблеми захисту житлових прав громадян в цивільному судочинстві» (2017).

Як відомо, в 2014 році відбулося зниження курсу національної валюти України, що породило низку проблем, особливо щодо виконання громадянами зобов'язань за іпотечними кредитами в іноземній валюті. Держава, ввівши мораторій на задоволення вимог комерційних банків за такими кредитами, відтермінувала вирішення цього питання, тим самим захистивши громадян від примусового продажу придбаного ними за іпотечними договорами житла, проте, переклавши тягар 
валютних ризиків на банківську систему. Наразі зняття мораторію породило хвилю звернень стягнень на заставлене житло, виконання яких потребувало нормативного врегулювання діяльності «колекторів». Підстави та процедура звернення стягнення на заставлене житло за іпотечними договорами повинні мати законний характер. Тим не менше, в цій сфері права громадян України доволі часто порушуються, що потребує удосконалення механізму їх захисту.

Окреме питання, яке не було предметом досліджень науковців, стосується захисту законних житлових інтересів фізичних осіб. У спеціальній науковій літературі ані питання правової характеристики законного житлового інтересу, ані його захисту не були предметом науковців. В першу чергу, йдеться про житловий інтерес як передумову набуття чи виникнення житлового права. Відтак, захист житлового інтересу є передумовою здійснення права на житло шляхом набуття відповідного конкретного суб'єктивного права особи в конкретному правовідношенні. Тож недооцінювати значення законного інтересу та його цивільно-правового захисту не варто. Серед інших, йдеться про відносини, пов'язані здіяльністю ОСББ (об'єднань співвласників багатоквартирних будинків) та сферою надання житлово-комунальних послуг. Останні, звичайно, $\epsilon$ залежними та взаємопов'язаними 3 житловими правами, оскільки визначають якість, а інколи і можливість здійснення права на житло стосовно конкретних житлових приміщень.

Закономірно, що не були предметом системного наукового дослідження суб'єктивні житлові права та особливості ї цивільно-правового захисту у відносинах при реалізації права на приватизацію державного житлового фонду, забезпечення житлом соціального призначення, здійснення прав мешканців гуртожитків, здійснення житлових прав учасників об'єднань співвласників багатоквартирних будинків та захисту їх прав і законних інтересів та компенсації особам, житло яких зруйноване внаслідок збройної агресії Росії на підконтрольних Україні територіях Донецької та Луганської областей та ін. Відтак, цивільно-правова характеристика особливостей цивільно-правового захисту законних житлових інтересів, захисту житлових прав, особливо в правовідносинах, які не були предметом системних наукових досліджень, проблемні питання цивільно-правового захисту прав та законних інтересів осіб за такими правовідносинами потребують свого з'ясування та вирішення.

Основний виклад. Визнання та закріплення права людини на житло на міжнародному рівні мало місце вперше в ст. 12 Загальної Декларації прав людини 1948 р. ${ }^{1}$, якою визначено, що ніхто не може зазнавати безпідставного втручання уйого особисте і сімейне життя, безпідставного посягання на недоторканність його житла. Важливою гарантією цього права $є$ закріплення положення, що кожна людина має право на захист закону від такого втручання або таких посягань.

Звертає увагу, що складові сучасного розуміння змісту права людини на житло було виокремлено в Декларації в окремі статті. Так, якщо ст. 12 визначає гарантії права людини на недоторканість житла, то ст. 25 орієнтована на забезпечення житлом в контексті складової життєвого рівня, який включає їжу, одяг, житло.

Європейською Конвенцією 1950 р. «Про захист прав людини і основоположних свобод» ${ }^{2}$ статтею 8 право людини на житло визначене в контексті критерію «поваги» до приватного і сімейного життя, до житла і кореспонденції. В статті 7 Хартії основних прав Європейського Союзу ${ }^{3}$ було застосовано той же критерій та зміст цього права.

В Контексті Європейської конвенції повага до житла означає дещо більше, аніж недоторканість житла і включає як безпеку помешкання, що забезпечує сферу приватності людини, так самої власності.

Житлові права перебувають в діалектичній залежності від самої категорії «житла» як об’єкта цивільних прав та об'єкта цивільних правовідносин, щодо якого у учасників таких відносин виникають певні суб'єктивні права та обов'язки.

Г.В. Самойленко та М.К. Галянтич у спільній статті аргументували, що зміст права на житло складають основні права людини: право людини на повагу до іiі житла, право на свободу вибору місця проживання, право на недоторканність житла; право на забезпечення житлом соціально незахищених

\footnotetext{
1 Загальна деклараиія прав людини, 1948 (ООН). Офіиійний сайт Верховної Ради Украӥни <https://zakon.rada.gov.ua/laws/show/995_015\#Tеxt> (2021, травень, 11).

${ }^{2}$ Європейська Конвенція Про захист прав людини і основоположних свобод, 1950 (Рада Європи). Офіційний сайт Верховної Ради України <https://zakon.rada.gov.ua/laws/show/995_004\#Tехt> (2021, травень, 11).

${ }^{3}$ Хартії основних прав Європейського Союзу, 2000 (Свропейський Союз) Офіційний сайт Верховної Ради

України <https://zakon.rada.gov.ua/laws/show/994_524\#Text> (2021, травень, 11).
} 
категорій населення України; на створення умов реалізації права людини на житло; речові та зобов'язальні права на житло ${ }^{1}$. Авторами було також висловлено позицію, що категорію «житла» варто розуміти через призму не лише як майнового, але й немайнового блага, що «відокремлює особливу приватну сферу особи, елементами якої $\epsilon$ його недоторканність та захист від несанкціонованого проникнення в нього інших осіб та невтручання у приватне життя» ${ }^{2}$.

T.I. Дудаш, аналізуючи зміст поняття права на житло, звернулася до справи «Akdivar and Others v. Turkey» ${ }^{3}$ в якій рішенням від 16.09.1996 р. Суд до ознак «житла» додав ознаку захищеності від нападів з боку держави чи навмисного руйнування іiі представниками ${ }^{4}$.

Вважаємо, що така ознака є не стільки характеристикою самого житла як об'єкта цивільних правовідносин, стільки ознакою права особи щодо такого об'єкта, яке включає не лише можливість здійснення відповідного права, але й його захист.

О.О. Кот визначив, що можливість захисту є гарантією самого суб'єктивного права. Він доволі справедливо зауважив, що проблема захисту цивільних прав $\epsilon$ актуальною 3 часів римського приватного права, яке переслідуючи прагматичну мету, розробило механізм захисту, чи механізм допомоги, який необхідно застосувати у випадку порушення суб'єктивного права, тим самим визнаючи, що лише судовий захист існуючого права давав йому справжню цінність і довершеність 5 .

Ним було визначено, що стосовно «захисту цивільних прав» існує, щонайменше три підходи: 1) «теорія функції», яка визначає захист однією з функцій права; 2) визначає «захист» через категорію системи застосованих заходів, що спираються на державний примус; 3) «теорія діяльності», в якій під захистом розуміється сама правозастосовна діяльність ${ }^{6}$. Прибічником останньої $є$ Ю.Д. Притика, на думку якого захист прав може визначатися як юридична діяльність, спрямована на усунення перешкод на шляху здійснення суб'єктивних прав та припинення правопорушення ${ }^{7}$.

Нам імпонує точка зору В.О. Тархова, в якій він визначив право на захист як міру дозволеної поведінки уповноваженої особи, що дозволяє носієві самостійно чи за допомогою державних органів застосувати до зобов'язаної особи заходи державно-примусового характеру з метою усунення перешкод у здійсненні суб'єктивного права, його відновлення чи покарання за порушення ${ }^{8}$.

Але і в такому підході $\epsilon$ низка зауважень. Так, ідеться про міру можливого носія суб'єктивного права вдатися до застосування певних заходів захисту. Але не варто їх плутати із заходами цивільно-правової відповідальності. Хоча і останній наразі не властива функція чи ознака «покарання» правопорушника. Крім того, навряд чи особа має можливість поза межами діяльності юрисдикційних органів застосувати до зобов'язаної особи заходи державнопримусового характеру. Останні тому і мають назву «державно-примусового характеру», оскільки вони санкціоновані державою i застосовуються виключно органами державної влади. Уповноваженими на їх застосування. Напевно, що особа самостійно може або вдатися до самозахисту, або пред'явити вимогу до порушника припинити порушення та відновити чи визначити порушене право, або звернутися з відповідним проханням до уповноважених юрисдикційних органів для застосування юрисдикційної форми захисту.

Самойленко Г.В. зробив висновок, що захист прав і цивільно-правова відповідальність співвідносяться як загальне і особливе. Цивільно-правова відповідальність $є$ одним із наслідків порушення договірного зобов'язання та способом захисту порушеного суб'єктивного права, а іiі функціональне призначення полягає в покладанні акцесорного обов'язку матеріального характеру на порушника. Ним також зроблено висновок, що вибір постраждалою особою форми та способу

\footnotetext{
${ }^{1}$ Галянтич, М. К., Самойленко, Г. В. (2015). Характеристика житла за цивільним законодавством України та в практиці Європейського суду з прав людини. Приватне право і підприємництво, 14, 138.

2 Там само, 134.

${ }^{3}$ European Court of Human Rights (1998). Akdivar and Others v. Turkey <https://hudoc.echr.coe.int/app/conversion/ pdf/?library=ECHR\&id=001-58152\&filename=001-58152.pdf\&TID=thkbhnilzk> (2021, травень, 11).

${ }_{4}^{4}$ Дудаш, Т. І. (2013). Практика Європейського суду з прав людини. Київ: Алерта.

${ }^{5}$ Кот, О. О. (2017). Здійснення та захист суб'єктивних изивільних прав: проблеми теорії та судової практики: монографія. Київ: Алерта, 176.

${ }^{6}$ Там само, 178 .

${ }^{7}$ Притика, Ю. Д. (2004). Поняття і диференціація способів захисту цивільних прав та інтересів. Вісник Київського національного університету імені Тараса Шевченка, 60-62, 16-17.

8 Тархов, В. А. (197). Гражданское право. Общая часть: курс лекций. Чебоксары: Чувашское книжное издательство, 269.
} 
захисту зумовлюється здатністю цього способу досягнути мети захисту та допуском його застосування актами спеціального законодавства ${ }^{1}$.

Н.С. Кузнєцова аргументувала, що цивільно-правова відповідальність $є$ невід'ємною частиною способів цивільно-правового захисту, що дозволяє співвідносити їх як загальне і особливе, де особливим є засоби цивільно-правової відповідальності, 3 чого нею зроблено висновок про самостійність цих інститутів ${ }^{2}$.

М.К. Галянтич, визначаючи особливості охорони та захисту житлових прав громадян, визначив речово-правові засоби захисту права власності на житло, до яких відніс: 1) витребування власником майна (житла) з чужого незаконного володіння (віндикаційний позов); 2) вимога власника про усунення перешкод з боку осіб, що заважають здійснювати право власності (негаторний позов); 3) вимога власника про звільнення майна з-під арешту. Відповідно, до зобов'язально-правових засобів захисту прав на житло він відніс: захист прав власності на житло в договірних відносинах (відшкодування збитків, заподіяних невиконанням чи неналежним виконанням договору; повернення речей, наданих за договором у користування і т.д.); способи захисту прав власності на житло в деліктних зобов'язаннях; повернення безпідставно отриманого чи збереженого майна. До спеціальних способів він відніс позови про визнання угоди недійсною, способи захисту права власності померлих та осіб, визнаних безвісно відсутніми чи оголошення померлими, захист прав власників від неправомірного втручання державних органів ${ }^{3}$.

Такий підхід наразі є традиційним у цивільному праві України: поділу способів захисту цивільних прав на речові та зобов'язальні. Та на жаль, у цій класифікації упущено засоби захисту особистих немайнових прав, тим більше, що обгрунтовувалося, що зміст права на житло включає як матеріальну, так і нематеріальну складову. Та все ж, пропонуючи таке доповнення, виходимо 3 можливості застосування для захисту порушеного житлового права чи законного інтересу переліку способів захисту цивільних прав та інтересів, визначених законодавцем в ст. 16 ЦК України: визнання права; визнання правочину недійсним; припинення дії, яка порушує право; відновлення становища, яке існувало до порушення; примусове виконання обов’язку в натурі; зміна правовідношення; припинення правовідношення; відшкодування збитків та інші способи відшкодування майнової шкоди; відшкодування моральної (немайнової) шкоди; визнання незаконними рішення, дій чи бездіяльності органу державної влади, органу влади Автономної Республіки Крим або органу місцевого самоврядування, їхніх посадових і службових осіб4.

Та попри закріплення загальних підходів, визначення способів захисту порушених житлових прав, на практиці їх реалізація виявляється інколи вкрай ускладненою.

Пояснюємо такий стан наступним. Погоджуючись загалом з М.К. Галянтичем, що зміст права на захист визначається комплексним поєднанням норм цивільного, матеріального і процесуального права, які встановлюють: 1) зміст правоохоронних заходів; 2) підстави їх застосування; 3) коло суб'єктів, уповноважених на їх застосування; 4) процесуальний i процедурний порядок їх застосування; 5) матеріально-правові і процесуальні права суб'єктів, щодо яких застосовуються відповідні заходи5, уточнюємо, що вади нормативно-правового регулювання житлових відносин доволі часто ускладнюють можливість здійснення право людини на захист житлових прав через недосконалість юридичної техніки складання актів законодавства.

Таким прикладом слугує положення норми п. 15 ст. 1 Закону України «Про забезпечення реалізації житлових прав мешканців гуртожитків» яка визначає проживання у гуртожитку протягом тривалого часу - проживання у гуртожитку постійно сукупно п'ять і більше років як умову здійснення права на реалізацію. Згідно цієї норми жительці м. Мелітополь було відмовлено у можливості приватизувати кімнату в гуртожитку, оскільки в 2015 році вона зверталася до коменданта із заявою не нараховувати платежі у липні-серпні (вода, газ, світло), оскільки вона на означений період від’їжджала за доглядом за своєю матір'ю до села.

\footnotetext{
${ }^{1}$ Самойленко, Г. В. (2021). Договір перевезення пасажира: теорія і практика забезпечення прав пасажира: дисертаиія на здобуття наукового ступеня доктора юридичних наук. Одеса: НУ «Одеська юридична академія», 404.

2 Кузнєцова, Н. С. (2014). Вибрані праиі. Київ: Юридична практика, 372.

3 Галянтич, М. К. (2008). Житлове право України: навчальний посібник. Київ: Юрінком Iнтер, 430-431.

${ }^{4}$ Цивільний кодекс Украӥни, 2003 (Верховна Рада України). Відомості Верховної Ради Украйни, 40-44, 356. <https://zakon.rada.gov.ua/laws/show/435-15\#Text> (2021, травень, 11).

${ }^{5}$ Галянтич, М. К. (2008). Житлове право Украӥни: навчальний посібник. Київ: Юрінком Інтер, 426-427.
} 
В іншому випадку порушено права співвласників багатоквартирного будинку. Згідно ст. 1 Закону України «Про об'єднання співвласників багатоквартирного будинку» ${ }^{1}$ таке об'єднання об'єднує як власників квартир, так і нежитлових приміщень багатоквартирного будинку. Стаття 15 цього закону закріплює обов'язок співвласників своєчасно і в повному обсязі сплачувати належні внески і платежі. Суд підтримав позицію юридичної особи - співвласника нежитлового приміщення щодо непідвідомчості спору між таким співвласником та ОСББ районному суду, тим більше що окремий договір між ними, як цього вимагає Господарський кодекс України, не укладався. Відтак, тягар утримання всього будинку має лягти на інших співвласників, що порушує їх законні житлові інтереси. Інша ситуація - коли співвласник відмовляється сплачувати такі платежі. ОСББ не має достатніх коштів оплачувати в такій ситуації вартість обслуговування та ремонту, включно, ремонт ліфту. Прийняття судового рішення про стягнення коштів з боржника в кращому випадку закінчиться накладанням арешту на нерухомість, що може завадити власнику лише у випадку відчуження ним такого майна. Враховуючи, що судовий збір за позовом юридичної особи складає 1,5 відсотка ціни позову, але не менше 1 розміру прожиткового мінімуму для працездатних осіб, який з 01 січня 2021 року складає 2 270,00 грн., та рахуючи вартість юридичної допомоги, ці кошти виявляться, скоріше за все «замороженими» і ще більше зменшать і без того бідний бюджет ОСББ. Тим самим можуть порушуватися не лише житлові, але й інші права та законні інтереси особи, що доволі відчутно при непрацюючому ліфті, та, особливо, при необхідності надання екстреної медичної допомоги, чи у випадку регулярного застрягання жильців в зламаному, але формально не аварійному ліфті.

Інша проблема виявилася при реалізації права на компенсацію узв'язку з руйнуванням житлових будинків (квартир) внаслідок надзвичайної ситуації воєнного характеру, спричиненої збройною агресією Російської Федерації, порядок якої закріплено Постановою Кабінету Міністрів України від 2 вересня 2020 р. № 767 «Питання виплати грошової компенсації постраждалим, житлові будинки (квартири) яких зруйновано внаслідок надзвичайної ситуації воєнного характеру, спричиненої збройною агресією Російської Федерації» ${ }^{2}$. Тут існує кілька проблем: 1) неможливість проведення обстеження в «сірій зоні» та неприйнятність доказів руйнування житла саме заявника; 2) невиконання обов'язку з проведення обстеження постраждалих від збройної агресії РФ житлових приміщень уповноваженими особами та відмова окружних адміністративних судів у прийнятті заяв про визнання незаконною протиправної бездіяльності таких суб' єктів до розгляду через підвідомчість таких справ районним судам, а районних судів - адміністративним окружним; 3) відмова в захисті порушених житлових прав громадян через відсутність затвердженої форми акту обстеження, який згідно Постанови Кабінету Міністрів України повинен затверджуватися Міністерством з питань тимчасово окупованих територій та внутрішньо переміщених осіб України (МТОТ).

Так, в Рішенні у справі № 360/4454/19 від 23 грудня 2019 року $^{3}$ Луганський окружний адміністративний суд, відмовляючи в захисті порушеного права позивача, в якому він просив суд визнати протиправною бездіяльність Попаснянської міської ради щодо відмови у наданні довідки про встановлення статусу особи, яка постраждала від надзвичайної ситуації, аргументував, що згідно зазначеної Постанови Кабінету Міністрів України органи місцевого самоврядування, а в разі їх відсутності - військово-цивільні адміністрації проводять обстеження пошкоджених або зруйнованих житлових будинків (квартир), обліковують їх, складають і затверджують списки постраждалих на відповідній території та видають довідки про встановлення статусу особи, яка постраждала від надзвичайної ситуації, а також видають акт обстеження за формою, що затверджується МТОТ. 3 цього судом зроблено закономірний висновок щодо обов язковості затвердження форми акту обстеження МТOT.

Суд визначив, що враховуючи відсутність правових підстав для складення акту обстеження пошкоджених або зруйнованих житлових будинків за відсутності затвердженої МТОТ форми

\footnotetext{
1 Закон України Про об’єднання співвласників багатоквартирного будинку, 2001 (Верховна Рада України). Відомості Верховної Ради України (ВВР), 10, 78.

2 Постанова про Питання виплати грошової компенсації постраждалим, житлові будинки (квартири) яких зруйновано внаслідок надзвичайної ситуації воєнного характеру, спричиненої збройною агресією Російської Федерації, 2020 (Кабінет Міністрів України). Офіційний сайт Верховної Ради Украӥни

<https://zakon.rada.gov.ua/laws/show/767-2020-\%D0\%BF\#Text> (2021, травень, 11).

${ }^{3}$ Рішення у справі № 360/4454/19, 2019 (Луганський окружний адміністративний суд). Сдиний державний реєстр судових рішень <https://reyestr.court.gov.ua/Review/86545652> (2021, травень, 11).
} 
акту, у відповідача не було підстав для видачі позивачці відповідної довідки, у зв язку із чим відмова з одночасним роз ясненням при цьому, що МТОТ не розроблено жодної форми документів на виконання Постанови КМУ від 10.07.2019 p. № 623, не порушила прав та законних інтересів позивача. Враховуючи вищевикладене, суд дійшов висновку про відмову у задоволенні позовних вимог.

Висновки. Попри загальне уявлення про достатність загальних положень ЦК України, якими закріплене право на захист цивільних прав та законних інтересів, способи судового захисту цивільних прав, здійснення цього права зумовлено особливостями механізму правового регулювання конкретних житлових відносин та відсутністю субмеханізму захисту порушеного, невизнаного чи оспореного житлового права чи житлового інтересу, що визначає потребу в: удосконаленні таких механізмів; уточненні та конкретизації змісту правоохоронних заходів, підстав їх застосування, кола суб'єктів, уповноважених на їх застосування, процесуального i процедурного порядків їх застосування; матеріально-правових і процесуальних прав суб'єктів, щодо яких застосовуються відповідні заходи.

\section{References:}

1. Zahalna deklaratsiia prav liudyny, 1948 (OON) [Universal Declaration of Human Rights, 1948 (UN)]. Ofitsiynyy sayt Verkhovnoyi Rady Ukrayiny [Official site of the Verkhovna Rada of Ukraine]

<https://zakon.rada.gov.ua/laws/show/995_015\#Text> (2021, May, 11). [in Ukrainian].

2. Konventsiia Pro zakhyst prav liudyny i osnovopolozhnykh svobod, 1950 [Convention On the Protection of Human Rights and Fundamental Freedoms, 1950]. Ofitsiynyy sayt Verkhovnoyi Rady Ukrayiny [Official site of the Verkhovna Rada of Ukraine] <https://zakon.rada.gov.ua/laws/show/995_004\#Text> (2021, May, 11). [in Ukrainian].

3. Khartiia osnovnykh prav Yevropeiskoho Soiuzu, 2000 (Yevropeiskij Soiuz) [Charter of Fundamental Rights of the European Union: International document, 2000 (EU)]. Ofitsiynyy sayt Verkhovnoyi Rady Ukrayiny [Official site of the Verkhovna Rada of Ukraine] <https://zakon.rada.gov.ua/laws/show/994_524\#Text> (2021, May, 11). [in Ukrainian].

4. Haliantych, M. K., Samoylenko, G. V. (2015). Kharakterystyka zhytla za tsyvilnym zakonodavstvom Ukrainy ta v praktytsi Yevropeiskoho sudu z prav liudyny. [Characteristics of housing under the civil legislation of Ukraine and in the case law of the European Court of Human Rights.]. Pryvatne pravo i pidpryiemnytstvo [Private law and entrepreneurship] [in Ukrainian].

5. European Court of Human Rights (1998). Akdivar and Others v. Turkey <https://hudoc.echr.coe.int-/app/-conversion/ pdf/?library=ECHR\&id=001-58152\&filename=001-58152.pdf\&TID-=thkbhnilzk $>$ (2021, May, 11). [in English].

6. Dudash, T. I. (2013). Praktyka Yevropeiskoho sudu z prav liudyny [The case law of the European Court of Human Rights]. Kyiv: Alerta. [in Ukrainian].

7. Kot, O. O. (2017). Zdiisnennia ta zakhyst subiektyvnykh tsyvilnykh prav: problemy teorii ta sudovoi praktyky: monohrafiia [Exercise and protection of subjective civil rights: problems of theory and case law: a monograph]. Kyiv: Alerta. [in Ukrainian].

8. Prytyka, Y. D. (2004). Poniattia i dyferentsiatsiia sposobiv zakhystu tsyvilnykh prav ta interesiv [The concept and differentiation of ways to protect civil rights and interests]. Visnyk Kyivskoho natsionalnoho universytetu imeni Tarasa Shevchenka [Bulletin of Taras Shevchenko National University of Kyiv]. [in Ukrainian].

9. Tarkhov, V. A. (1997). Hrazhdanskoe pravo. Obshchaia chast: kurs lektsyi [Civil law. General part: a course of lectures]. Cheboksary: Chuvashskoe knyzhnoe yzdatelstvo [Chuvash Book Publishing House]. [in Russian].

10. Samoylenko, G. V. (2021). Dohovir perevezennia pasazhyra: teoriia i praktyka zabezpechennia prav pasazhyra [The contract of carriage of the passenger: the theory and practice of maintenance of the rights of the passenger]: dysertatsiia doktora yurydychnykh nauk [The dissertation of the doctor of legal sciences]. NU "Odessa Law Academy". [in Ukrainian].

11. Kuznietsova, N. S. (2014). Vybrani pratsi [Selected works]. Kyiv: Legal Practice. [in Ukrainian].

12. Haliantych, M. K. (2008). Zhytlove pravo Ukrainy: navchalnyi posibnyk [Housing law of Ukraine: a textbook]. Kyiv: Yurinkom Inter. [in Ukrainian].

13. Tsyvilnyi kodeks Ukrainy, 2003 (Verkhovna Rada Ukrainy). [The Civil Code of Ukraine 2003 (Verkhovna Rada of Ukraine)]. Ofitsiynyy sayt Verkhovnoyi Rady Ukrayiny [Official site of the Verkhovna Rada of Ukraine] <https://zakon.rada.gov.ua/laws/show/435-15\#Text> (2021, May, 11). [in Ukrainian].

14. Zakon Ukrainy Pro obiednannia spivvlasnykiv bahatokvartyrnoho budynku, 2001 (Verkhovna Rada Ukrainy) [Law of Ukraine On the association of co-owners of an apartment building, 2001 (Verkhovna Rada of Ukraine)]. Vidomosti Verkhovnoi Rady Ukrainy [Information of the Verkhovna Rada of Ukraine]. (2021, May, 11). [in Ukrainian].

15. Postanova Pytannia vyplaty hroshovoi kompensatsii postrazhdalym, zhytlovi budynky (kvartyry) yakykh zruinovano vnaslidok nadzvychainoi sytuatsii voiennoho kharakteru, sprychynenoi zbroinoiu ahresiieiu Rosiiskoi Federatsii, 2020 (Kabinet Ministriv Ukrainy) [Resolution of the issue of payment of monetary compensation to victims whose 
houses (apartments) were destroyed as a result of a military emergency caused by the armed aggression of the Russian Federation, 2020 (Cabinet of Ministers of Ukraine)]. Ofitsiynyy sayt Verkhovnoyi Rady Ukrayiny

[Official site of the Verkhovna Rada of Ukraine] <https://zakon.rada.gov.ua/laws/show/767-2020-\%D0\%BF\#Text> (2021, May, 11). [in Ukrainian].

16. Rishennya u spravi № 360/4454/19, 2019 (Luhanskyy okruzhnyy administratyvnyy sud) [Decision in the case № 360/4454/19, 2019 (Luhansk District Administrative Court)]. Yedynyy derzhavnyy reyestr sudovykh rishen [Unified state register of court decisions] <https://reyestr.court.gov.ua/Review/86545652> (2021, May, 11). [in Ukrainian]. 